\title{
Development and characteristics of microsatellite markers for sugi (Cryptomeria japonica D. Don) derived from microsatellite-enriched libraries
}

\author{
Naoki TANI $^{\mathrm{a}}$, Tomokazu TAKAHASHI ${ }^{\mathrm{b}}$, Tokuko UJINO-IHARA ${ }^{\mathrm{a}}$, Hiroyoshi IWATA ${ }^{\mathrm{a}, \mathrm{c}}$, \\ Kensuke YosHIMURA ${ }^{\mathrm{a}}$, Yoshihiko TSUMURA ${ }^{\text {a* }}$ \\ ${ }^{a}$ Department of Forest Genetics, Forestry and Forest Products Research Institute, Matsunosato, Tsukuba, Ibaraki 305-8687, Japan \\ b Graduate School of Science and Technology, Niigata University, Ikarashi, Niigata 950-2181, Japan \\ ${ }^{\mathrm{c}}$ Present address: National Agricultural Research Center, Kannondai, Tsukuba, Ibaraki 305-8666, Japan
}

(Received 11 July 2003; accepted 18 March 2004)

\begin{abstract}
We have developed a series of microsatellite markers for $C$. japonica. First, DNA fragments including microsatellite sequences were isolated from two GA-enriched genomic libraries using magnetic beads. After eliminating redundant clones and clones in which the tandem repeats were located too close to the cloning site to allow primers to be constructed, the remaining sequences could be examined for their suitability for primer design. Primer sets were designed from each conserved sequence flanking the microsatellites. We found 1479 unique sequences in the enriched genomic libraries, of which 962 contained a tandem repeat motif, and we have been able to design 196 primer pairs using these sequences to date. The potential of these primers to amplify single fragment, and the polymorphism of the sequences they amplify, were investigated using a panel of 28 plus trees selected from Cryptomeria plantations covering the wide distributional range of the species in Japan. Forty-two of the microsatellite markers displayed a polymorphic nature throughout this panel of 28 DNA samples. The polymorphic information coefficients (PICs) ranged from 0.156 to 0.919 . There was a significant correlation, between the number of repeats and the size of the PICs, according to Kendall's $\tau$ rank correlation coefficient analyses.
\end{abstract}

taxodiaceae / conifer / simple sequence repeat / enrichment / primer

Résumé - Développement et caractéristiques de marqueurs microsatellites pour le sugi (Cryptomeria japonica D. Don) trouvés dans des banques microsatellites enrichies. Nous avons développé une série de marqueurs microsatellites pour Cryptomeria japonica. Dans un premier temps, des fragments d'ADN comportant des séquences microsatellites ont été isolées à partir de 2 banques de séquences génomiques enrichies en GA, grâce à l'utilisation de billes magnétiques. Puis, après avoir éliminé les clones redondants et les clones pour lesquels les séquences en tandem étaient trop proches du site de clonage pour permettre aux amorces d'être construites, les séquences restantes ont été examinées afin de determiner si elles convenaient pour la construction d'amorces. Des jeux d'amorces ont été conçus à partir de chaque séquence conservée flanquant les microsattelites. Nous avons trouvé 1479 séquences uniques dans les banques génomiques enrichies, parmi lesquelles 962 contenaient 1 motif répété en tandem, et à ce jour, nous avons pu concevoir 196 paires d'amorces en utilisant ces séquences. Les capacités de ces amorces à amplifier un fragment unique, ainsi que le polymorphisme des séquences que nous avons amplifiées, ont été étudiées à partir d'un échantillon de 28 arbres «plus » sélectionnés à partir de plantations de Cryptomeria couvrant la totalité de l'aire de répartition au Japon. Quarante-deux de ces marqueurs microsatellites se sont révélés polymorphes au sein de cet échantillon. Les coefficients d'information sur le polymorphisme (PIC : Polymorphism Information Coefficient) varient de 0.156 à 0.919. Les analyses de coefficients de corrélation de rangs de Kendall ont mis en évidence une corrélation significative entre le nombre de répétitions et la valeur des PIC.

taxodiacée / conifère / répétition de séquence simple / enrichissement / amorce

\section{INTRODUCTION}

Microsatellites, also known as single sequence repeats (SSRs), occur as tandem arrays of mono-, di-, tri-, tetra- or penta-nucleotide repeat units in many plant and animal species [30]. The variability of the number of repeat units at a particular locus and the conservation of the sequences flanking the tan- dem repeat make microsatellites valuable, codominant genetic markers [30]. When microsatellite markers for a particular species are developed, their capacity to be amplified by PCR allows large-scale genotyping on automated DNA analyzers for the construction of genetic linkage maps, and facilitates studies of population genetics and reproduction ecology. For these reasons, microsatellite markers have been developed for

\footnotetext{
* Corresponding author: ytsumu@ @ffri.affrc.go.jp
} 
use in analyses of a number of coniferous species (see, for instance, [1, 3, 9, 10, 18, 20, 34, 36]).

Sugi (Cryptomeria japonica) is the most important forest tree species in Japanese forestry. Plantations of the species are widely distributed in Japan, from the southern part of Hokkaido to Yaku-shima island off the coast of Kyushu. C. japonica has been subjected to intensive genetic investigations, including the construction of genetic linkage maps [14, 19, 22, 24, 28], analysis of its genetic population structure and reproductive systems [21, 27, 29, 31, 33], and development of genetic markers [14, 20, 32]. In a recent study, Moriguchi et al. [20] developed 34 microsatellite markers from a microsatellite-enriched library and cDNA libraries for use in paternity analyses within seed orchards of $C$. japonica. However, the number of microsatellite markers was insufficient to construct genetic linkage maps, or for population genetic studies covering desired proportions of the $C$. japonica genome. Use of multiple pedigrees is an efficient approach for constructing genetic linkage maps for species with allogamous characteristics, such as coniferous species, and microsatellite markers can provide valuable bridges when integrating independent genetic linkage maps derived from different pedigrees. Therefore, we have continued to develop additional microsatellite markers.

\section{MATERIALS AND METHODS}

\subsection{Construction of microsatellite enrichment libraries}

We successfully constructed or acquired two microsatelliteenriched libraries. One, designated CS, was constructed by Genetic Identification Service Inc. (Chatsworth, USA), and we constructed the other, named CJS, as follows. Five micrograms of genomic DNA was extracted from needles of a $C$. japonica tree growing in a nursery of the Forestry and Forest Products Research Institute by the modified CTAB method [23]. It was then purified by equilibrium centrifugation in CsCl-ethidium bromide gradients [26] to construct an enriched microsatellite library according to modified methods published by Armour et al. [2], Fleischer and Loew [12] and Fischer and Bachmann [11]. The genomic DNA was digested with the restriction enzyme NdeII, and fragments ranging from 300 to 1,000bp in size were ligated into Sau3AI linkers (TaKaRa, Kyoto, Japan). DNA fragments with linkers were resolved in binding buffer $(10 \mathrm{mM}$ Tris-HCl, $1 \mathrm{mM}$ EDTA, $100 \mathrm{mM} \mathrm{NaCl}, \mathrm{pH}$ 7.5) and hybridized to 5' biotin-labeled oligonucleotide probes $\left(5^{\prime}\right.$ biotin $\left.(\mathrm{CT})_{15} 3^{\prime}\right)$ after denaturation. The DNA molecules bound to the biotin-labeled probes were subsequently isolated by binding them to streptavidin-coupled (M-280) Dynabeads ${ }^{\circledR}$ (Dynal Biotech, Oslo, Norway). After rinsing the beads in two kinds of washing buffer $(2 \times \mathrm{SSC}, 0.1 \%$ SDS and $1 \times \mathrm{SSC}, 0.1 \%$ SDS $)$, target DNAs were recovered by denaturing them in boiled water. The resulting fragments were then amplified by PCR and digested with NdeII to remove the linkers. The enriched fragments selected in this way were ligated into pUC118/BamHI (TaKaRa, Kyoto, Japan) and cloned into competent cells (Escherichia coli DH5). Plasmids from these clones were prepared using the Wizard ${ }^{\circledR}$ SV96 system (Promega, Madison, USA) and sequenced using a 3100 DNA sequencer with a BigDye Terminator kit (PE Applied Biosystems, Foster, USA).

\subsection{Primer design, PCR and electrophoresis}

Primer pairs were designed using OLIGO 5.0 software (Molecular Biology Insights, Inc., Cascade, USA). Subsequent PCR amplification was performed in $20 \mu \mathrm{L}$ reaction volumes containing $0.2 \mu \mathrm{M}$ of each primer, $0.2 \mathrm{mM}$ of each dNTP, $20 \mathrm{mM}$ Tris- $\mathrm{HCl}(\mathrm{pH} \mathrm{8.4),} 50 \mathrm{mM} \mathrm{KCl}$, $1.5 \mathrm{mM} \mathrm{MgCl}_{2}, 0.25 \mathrm{U}$ of Taq DNA polymerase and $0.5-3 \mathrm{ng}$ of template DNA using a PTC200 DNA Engine Thermal Cycler with gradient temperature control (MJ Research, Inc., Waltham, USA). The thermal program was as follows: 4 min at $94{ }^{\circ} \mathrm{C}$, then $30-35$ cycles of $45 \mathrm{~s}$ at $94^{\circ} \mathrm{C}$, a $45 \mathrm{~s}$ gradient from 45 to $65^{\circ} \mathrm{C}$ and $45 \mathrm{~s}$ at $72{ }^{\circ} \mathrm{C}$, finishing with $5 \mathrm{~min}$ at $72{ }^{\circ} \mathrm{C}$. The fragments resulting from the PCR amplifications were electrophoretically separated in $7.5 \%$ polyacrylamide gels and stained by ethidium bromide. They were then examined to identify primer pairs yielding clear single bands and to optimize the annealing temperature and number of PCR cycles for each pair of primers selected.

\subsection{Plant materials, polymorphism and inheritance of microsatellite markers in $C$. japonica}

Microsatellite sequences detected from the two enriched libraries were classified into three categories (perfect, imperfect and compound repeats), as defined by Weber [35]. The potential value of these primers for use as microsatellite markers and for evaluating polymorphism was investigated using a panel of DNAs from 28 plus trees (see Fig. 1) selected from Cryptomeria japonica plantations covering the species' wide distributional range in Japan. The segregation of alleles at 42 microsatellite loci was compared with expected Mendelian ratios by $\chi^{2}$ tests. For this, a segregating population of 150 trees was produced from a cross between two full-sib trees originating from a cross between 'Iwao (female)' and 'Yabukuguri (male)', which are local cultivars of C. japonica. The DNAs were extracted from needle tissue using a modified CTAB method [22]. PCR amplifications were carried out using a GeneAmp PCR System Model 9700 (Applied Biosystems) in a total volume of $20 \mu \mathrm{L}$ including $0.2 \mu \mathrm{M}$ of each primer, $0.2 \mathrm{mM}$ of each dNTP, $20 \mathrm{mM}$ Tris- $\mathrm{HCl}$ (pH 8.4), $50 \mathrm{mM} \mathrm{KCl}, 1.5 \mathrm{mM} \mathrm{MgCl}_{2}$, $0.25 \mathrm{U}$ of Taq DNA polymerase and $0.5-3 \mathrm{ng}$ of template DNA, with the following temperature profile: $4 \mathrm{~min}$ at $94^{\circ} \mathrm{C}$ then $30-35$ cycles of $45 \mathrm{~s}$ at $94^{\circ} \mathrm{C}, 45 \mathrm{~s}$ at $55-60{ }^{\circ} \mathrm{C}$ and $45 \mathrm{~s}$ at $72{ }^{\circ} \mathrm{C}$, followed by $5 \mathrm{~min}$ at $72{ }^{\circ} \mathrm{C}$. PCR fragments amplified from these sample DNAs using the microsatellite primers were electrophoretically separated on $7.5 \%$ polyacrylamide gels, stained by ethidium bromide, and visualized under a UV illuminator (Fig. 1).

\subsection{Data analysis}

From the genotype data of the 28 trees comprising the screening panel, the number of alleles per locus (NA), and polymorphism information content, PIC, [4], were obtained for each locus using the program G-DIVERSE developed by H. Iwata. The PIC was calculated as follows:

$$
\mathrm{PIC}=2 \sum_{i=2}^{l} \sum_{j=1}^{i-1}\left[P_{i} P_{j}\left(1-P_{i} P_{j}\right)\right],
$$

where, $p_{i}$ and $p_{j}$ refer to the frequency of alleles $A_{i}$ and $A_{j}$, respectively, and summation extends over $l$ alleles.

The relationships between polymorphic parameters (NA and PIC) and characteristics of the microsatellite sequences, such as the number of repeats (NOR), the number of nucleotides per repeat (NNR), the total number of nucleotides (TNN) and the number of nucleotides in flanking regions of the microsatellites (NNF) were examined using JMP 4 software (SAS Institute) to calculate Kendall's rank correlation coefficients [16]. 

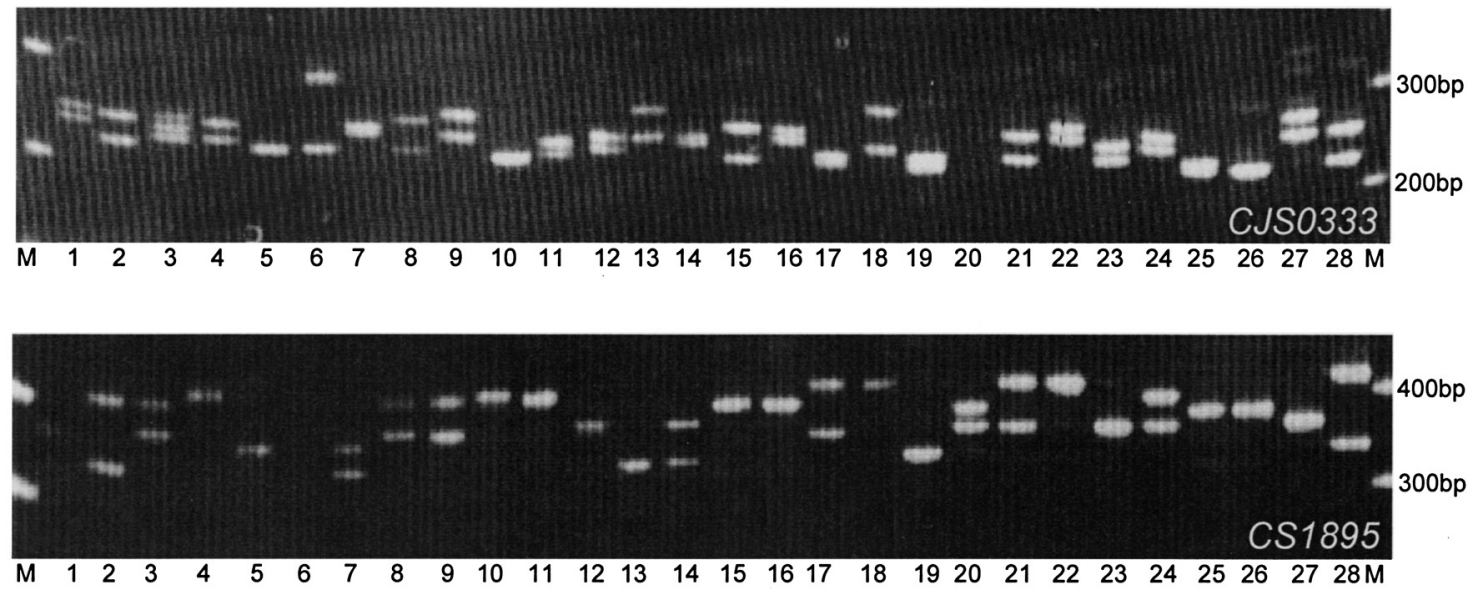

Figure 1. Microsatellite markers, CJS0333 and CS1895, developed for surveying levels of polymorphism in the panel of 28 plus trees, electrophoretically separated in $7.5 \%$ polyacrylamide gels. M stands for marker lanes. Lanes 1 to 28 , numbered from right to left, correspond to: 1, Hamamatsu 1; 2, Nishikawa 16; 3, Gifu 2; 4, Higashiusuki 14; 5, Gujyo 5; 6, Kusu 12; 7, Fukuokasho 2; 8, Satsuma 3; 9, Ishikawa 5; 10, Syochiku 6; 11, Tone 6; 12, Haara; 13, Kumotoshi; 14, F1 of Kumotoshi $\times$ Haara; 15, Minaminasu 3; 16, Takasaki 4; 17, Numata 4; 18, Kuji 3; 19, Inashiki 2; 20, Hiki 13; 21, Nagano 2; 22, Ohi 2; 23, Tenryu 6; 24, Minamiaizu 1; 25, Imaichi 2; 26, Ohtsuki 5; 27, Higashikamo 8; 28, Nukata 3, respectively.

\section{RESULTS AND DISCUSSION}

\subsection{Sequences of clones from the two microsatellite-enriched libraries}

We sequenced 1079 clones from the CS library. The data showed 413 (38.3\%) of these clones to be redundant and 665 to be unique, 202 of which included microsatellite sequences. By contrast, the CJS library showed a low redundancy ratio, $15.8 \%$, and it contained 760 (out of a total of 814) unique sequences that included microsatellite sequences. Thus, in total, we obtained 962 unique sequences including microsatellite motif sequences (Tab. I). In addition, we found di-nucleotide and tri-nucleotide repeat types of microsatellite motif permutations in both of our libraries. The microsatellite sequences were classified into microsatellite motif permutations according to Echt and May-Marquardt [8]. 46\% (CS) and $87 \%$ (CJS) of the microsatellite sequences were assigned into the poly(AG)n category of microsatellite sequence permutations, which we expected to find, since we used a (CT)n repeat oligo-nucleotide probe for the enrichment of microsatellite fragments. Nevertheless, despite using the (CT)n probe, 74 and 142 clones including microsatellite sequences with $(\mathrm{AC})$ permutations were detected in the CS and CJS libraries, respectively. Most of the poly(AC)n sequences (21 in CS and 104 in CJS) were accompanied with poly(CT)n sequences, explaining why they were captured in the microsatellite-enriched libraries by the (CT)n oligo-nucleotide probe. However, the other clones with poly(AC)n sequences did not include any other microsatellites with different types of motif. A large-scale survey of microsatellite sequences in a rice genomic library found an estimated 1360 poly(GA)n and 1230 poly(GT)n microsatellites in the rice genome [25]. If $C$. japonica genome also possesses abundant poly(AC)n microsatellites, as the rice genome appears
Table I. Results of sequencing SSR-enriched genomic libraries from Cryptomeria japonica.

\begin{tabular}{lccc}
\hline $\begin{array}{l}\text { Designation } \\
\text { of genomic } \\
\text { library }\end{array}$ & $\begin{array}{c}\text { Number } \\
\text { of clones } \\
\text { sequenced }\end{array}$ & $\begin{array}{c}\text { Number of clones } \\
\text { with unique } \\
\text { sequences }\end{array}$ & $\begin{array}{c}\text { Number of clones } \\
\text { with unique } \\
\text { sequence and SSRs }\end{array}$ \\
\hline CS & 1079 & 665 & 202 \\
CJS & 967 & 814 & 760 \\
Total & 2046 & 1479 & 962 \\
\hline
\end{tabular}

to do, it is possible that we detected microsatellites with this type of motif by chance. We also detected two other di-nucleotide repeat types of motif and seven tri-nucleotide repeat types of motif, but the number of microsatellites involved in these cases was very small (Tab. II).

Microsatellite markers have been developed for various coniferous species using microsatellite-enrichment methods (see, for instance, $[1,10,37]$. Our successful construction of microsatellite-enriched genomic libraries also showed that enrichment using magnetic particles can promote the efficiency of the development of large amounts of microsatellite markers for coniferous species.

\subsection{Characterization and polymorphisms of microsatellite markers}

PCR primer pairs were able to design for 196 clones, which showed clear sequence and have enough sequence length for the flanking region of SSR. Forty-two new primers that performed as microsatellite markers were chosen out of the 196 primer pairs we constructed because they detected polymorphisms and gave clear banding patterns when subjected to $7.5 \%$ 
Table II. Summary of numbers of SSRs found in two genomic libraries enrichied by the CT repeat probe. Roman numbers showed a kind of repeat motif of dinucleotide or trinucleotide. The dinucleotide and trinucleotide repeats have four and six kinds of motif, respectively, thus, the roman numers are corresponding to their motifs.

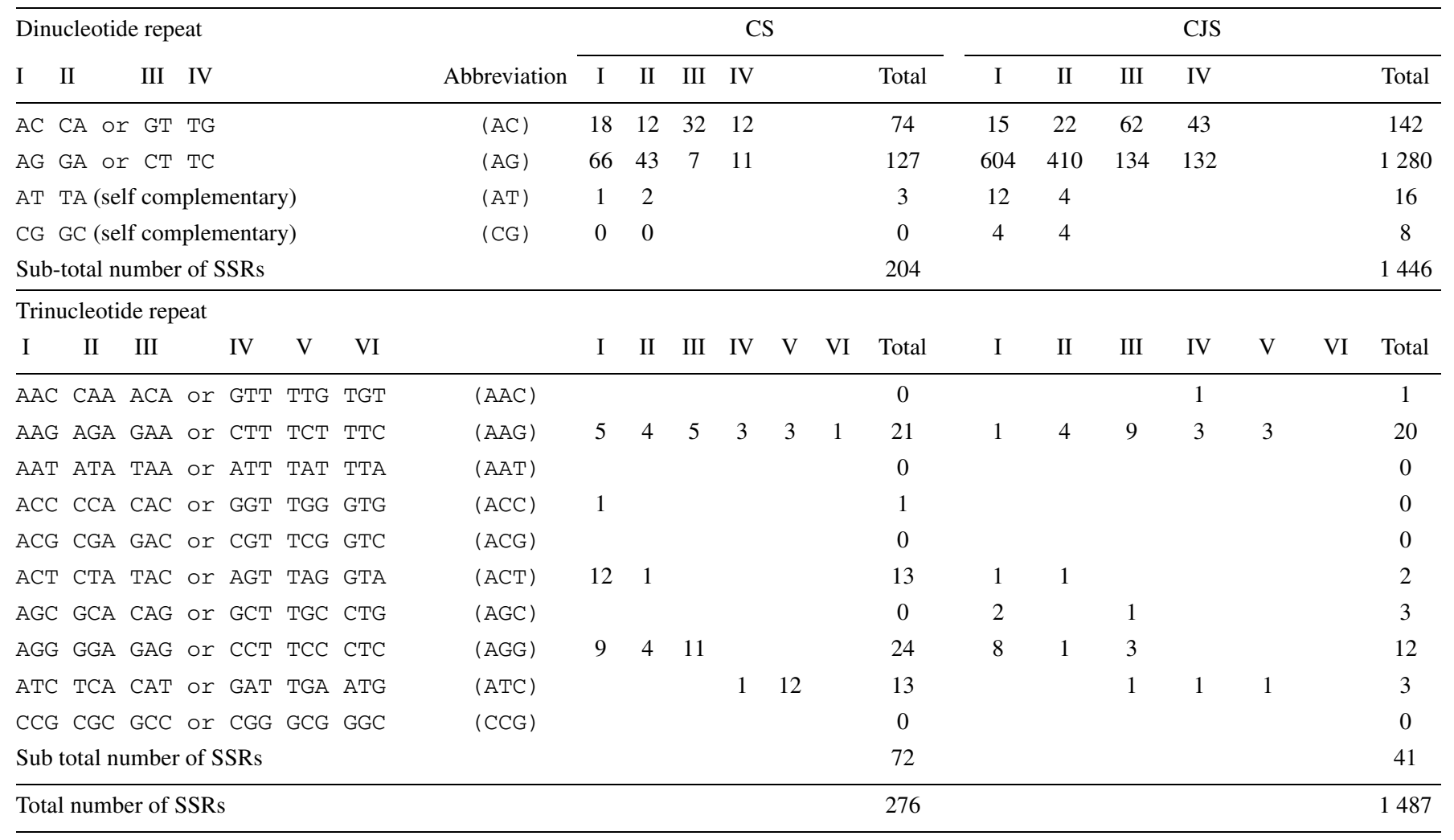

polyacrylamide electrophoresis (Fig. 1). The primer sequences and PCR conditions for these loci are listed in Table III. The panel of 28 plus trees allowed the polymorphic levels at these loci to be evaluated using two statistics: the number of alleles per locus (NA) and the polymorphism information content (PIC). NA and PIC values generated from the 28 plus trees ranged from 3 to 20 with an average of 7.38 , and from 0.156 to 0.919 with an average of 0.620 , respectively (Tab. IV). We then examined the correlations between two measures of polymorphic levels (NA and PIC) on one hand, and two measures of the length of repeat unit (NOR and NNR), total number of nucleotides (TNN) and a measure of the number of nucleotides in flanking regions of microsatellites (NNF) on the other by Kendall's rank order tests. The degree of polymorphism, according to the derived PIC and NA values, was strongly correlated to the length of the repeat units (NOR and NNR). However, there was no correlation between the polymorphic level and both the total number of nucleotides (TNN) and the length of the flanking region (NNF; Tab. V). In some previous characterizations of microsatellite sequences, evidence for not only nucleotide substitutions, but also indels has been detected in flanking sequences of microsatellites $[6,17]$. However, mutations in the flanking regions of the microsatellites do not appear to have affected the degree of polymorphism amongst the microsatellite markers we studied at a statistically significant level according to the Kendall's correlation analysis. Most of the length variation of the PCR products from microsatellite mark- ers might depend upon slippage mutations of the microsatellite sequences.

\subsection{Segregation analysis}

Segregation in the sib-crossed pedigree was assessed at 42 microsatellite loci (Tab. IV). Twenty-eight and 14 loci were found to be polymorphic and monomorphic in the investigated pedigree, respectively. According to the results of the $\chi^{2}$ tests, no statistically significant deviations were detected at 26 microsatellite loci. However, we detected statistically significant deviations (at the $5 \%$ probability level) at two microsatellite loci, CS2260 and CS2294. The expected segregation ratio at the CS2260 locus was 1:1, because one of the parents was a heterozygote and the other was a homozygote. The expected segregation ratio at the CS2294 locus was 1:2:1, because both parents were heterozygous, with the same genotype. For both of the microsatellite loci showing evidence of segregation distortion, we detected heterozygote excess in 150 individuals of the segregation generation. Inbreeding depression due to the sib-cross or to random chance may have been responsible for this segregation distortion. We detected null alleles (nonamplifying alleles) that may have been due to mutation at the priming sequence at only four loci $[5,15]$. By contrast, Moriguchi et al. [20] detected null alleles at 12 out of 34 loci developed $(35.3 \%)$ in a previous segregation analysis using the same pedigree as in this study, and deduced that the high rate of null allele detection was caused by a high mutation rate at 
Table III. Description of sugi microsatellite markers.

\begin{tabular}{|c|c|c|c|c|c|c|c|c|}
\hline Locus & $\begin{array}{l}\text { Forward primer } \\
5^{\prime} \text { to } 3^{\prime}\end{array}$ & $\begin{array}{l}\text { Reverse primer } \\
5^{\prime} \text { to } 3^{\prime}\end{array}$ & $\begin{array}{l}\text { Anneal } \\
\text { temp. }\end{array}$ & $\begin{array}{l}\text { PCR } \\
\text { cycle }\end{array}$ & $\begin{array}{c}\text { DDBJ } \\
\text { accession No. }\end{array}$ & Motif & $\begin{array}{l}\text { Putative } \\
\text { size }(b p)^{a}\end{array}$ & $\begin{array}{c}\text { Repeat } \\
\text { status }\end{array}$ \\
\hline CJS0002 & CTTTTTTCAAATTTAGTGATGT & CCCATGCCCCACTGTCCACC & 55 & 30 & AB161634 & (TC)12(TC)17 & 237 & Imperfect \\
\hline CJS0091 & GAGAGATAAGAGGGTAGAGGT & CAATGCCAACTTAGAAGAC & 60 & 30 & AB161635 & (GA)43 & 298 & Perfect \\
\hline CJS0268 & CCTTAGAAAGCTATGCCAC & GCAACGCATCCATAATACC & 60 & 30 & AB161636 & (AC) 53 & 352 & Perfect \\
\hline CJS0331 & GGAGAGATAGACGACAAAAGAG & CCATCTTGCTAATCTGTCC & 60 & 30 & AB161637 & $(\mathrm{GA}) 6$ & 245 & Perfect \\
\hline CJS0333 & AGGAGATTAGGATGGTGGG & GGTTTGCCTCTTCTATGAG & 60 & 30 & AB161638 & $(\mathrm{GA}) 26$ & 264 & Perfect \\
\hline CJS0336 & CAGGGAGTGGTTAAGGGAG & СТТССАТСТСТТСССАТСТС & 60 & 30 & AB161639 & $(\mathrm{GA}) 11(\mathrm{GA}) 40$ & 259 & Compound \\
\hline CJS0356 & CTAAAGAATAGATGACTCCAC & TATAACGCTTTTGCCCTCA & 60 & 30 & AB161640 & (GA)64 & 337 & Perfect \\
\hline CJS0401 & GATCTAAACTTGAGCATAAC & CAATCCTGTCTCCATACCC & 55 & 30 & AB161641 & (CG)8(GA)54 & 222 & Compound \\
\hline CJS0455 & GTTACTTTGAAAAATGAGCC & AACATCAAGATTAAAGGGAC & 58 & 30 & AB161642 & (CT)20 & 166 & Perfect \\
\hline CJS0485 & CATATCTAATATCTAATACCTTG & TCTCCСТATCTAGCCCTCTG & 50 & 35 & AB161643 & $\begin{array}{c}(\mathrm{GA}) 9(\mathrm{GA}) 30(\mathrm{GA}) \\
27\end{array}$ & 331 & Compound \\
\hline CJS0520 & TCCCTTTTGGTATTTTACAC & ACTCAAATTGCGATAATCTC & 55 & 30 & AB161644 & (TG)18 & 196 & Perfect \\
\hline CJS0527 & ATAGAAGAAGAGAAGTAGGG & TCATATCGTGTCATGTGTCC & 55 & 30 & AB161645 & $(\mathrm{GA}) 18$ & 103 & Perfect \\
\hline CJS0537 & ATGAAGGGAATGATTGATGG & TCTCTCACTTGGGTTCTCTC & 55 & 30 & AB161646 & (GA)34(AG)6 & 163 & Compound \\
\hline CJS0584 & TGGTTTGCCTTTGGTTGCTC & GGACTTTCTATTTACCTCTTGG & 60 & 30 & AB161647 & $(\mathrm{AG}) 80$ & 329 & Perfect \\
\hline CJS0665 & CCAAGCATAGGGAAAAAGAG & GGGGAGTAAGGATGACATTT & 60 & 30 & AB161648 & (GA) $45(\mathrm{GA}) 29$ & 367 & Imperfect \\
\hline CJS0686 & ACATGCAAATATAAGTTCACCC & ТССАССТСТТТTТСАТТСТС & 55 & 30 & AB161649 & $(\mathrm{GA}) 52$ & 275 & Perfect \\
\hline CJS0838 & TATGTAGAAGCGTGTGATGT & GATAATTGCCTTTGTTGTCC & 58 & 30 & $\mathrm{AB} 161650$ & (GT) 23 & 170 & Perfect \\
\hline CJS0955 & CACACTCCCCGTCTCCGACAG & ACCCTGATTCCCCATACACC & 58 & 30 & AB161651 & $(\mathrm{TCT}) 4(\mathrm{GA}) 29$ & 137 & Compound \\
\hline CS1218 & CATCACATACAAATAGCACC & GAAGATTGTCTCACGCACTC & 60 & 30 & $\mathrm{AB} 161652$ & (GT) 13 & 332 & Perfect \\
\hline CS1219 & AAGGTGTTGTTTTAAGGAGG & CAGCCATCTATTATTTGTGC & 60 & 30 & AB161653 & (GT) 10 & 103 & Perfect \\
\hline CS1226 & CTCTAGTCCTCAATGGTGGT & TATTAAGCATTTTCCCTCTC & 60 & 35 & $\mathrm{AB} 161654$ & (CA) 14 & 139 & Perfect \\
\hline CS1281 & СССССТСТCATTAGTTACCA & CAAAAATCAACAAGCCAACC & 60 & 30 & AB161655 & (CT) 15 & 233 & Perfect \\
\hline CS1289 & CATCCACCACTAAATACAAC & TCGCTATCCCTTGCCTATCC & 60 & 35 & AB161656 & $(\mathrm{AC}) 26(\mathrm{~A}) 26$ & 147 & Compound \\
\hline CS1364 & TGATTATGGTCGGTGGTCTT & GTGATGTGGTGTTATCTTGT & 62 & 30 & AB161657 & $(\mathrm{AC}) 7$ & 297 & Perfect \\
\hline CS1450 & GGCATTAAACCATCAAGACA & AGTTGGGCAGAGATCATAAG & 62 & 35 & AB161658 & (TG)9 & 401 & Perfect \\
\hline CS1522 & AAAGTTTGATTAGGGCAGGG & AAACGTGGGTGCTATCCTTC & 62 & 30 & AB161659 & (AC) 16 & 222 & Perfect \\
\hline CS1525 & ATGAAGTGCCCTTGGTTTGT & ATCGCCTCCTCTTTTATCCT & 60 & 30 & AB161660 & (CA) 18 & 200 & Perfect \\
\hline CS1579 & ACTCTAGCAGCATTTCTCAC & CAGATTTTGTATGAGTGGTT & 60 & 30 & AB161661 & (TG)11 & 291 & Perfect \\
\hline CS1671 & ACTTGTCCGCTTTTGTTGTT & GCCTCAAGGTAGGAGAAGAA & 60 & 30 & AB161662 & (TG) 16 & 280 & Perfect \\
\hline CS1737 & TACССТCAАСССТTCACCСТ & TTAСССАССТСТСТTТССТС & 60 & 30 & AB161663 & (AG)40 & 248 & Perfect \\
\hline CS1895 & TGAGAGAGGGAGGGAGGGTT & GAGTCCTTGTCCCGTTTTGT & 60 & 30 & AB161664 & (TG) 10 & 405 & Perfect \\
\hline CS1906 & AGTCATTCCCAGGCAGTGTC & АТСССТССАССТСТССТАСС & 60 & 30 & AB161665 & (TGA)6 & 346 & Perfect \\
\hline CS2024 & AGTAATACAAGATAAGGGAG & TCСАССТСТАТАССТСТАСА & 55 & 30 & AB161666 & $\begin{array}{c}(\mathrm{AG}) 15(\mathrm{AG}) 4(\mathrm{AG}) \\
10\end{array}$ & 314 & Imperfect \\
\hline CS2048 & СССТСТАТСТТСАТСТСТТС & AGGGATAGATATAGGGGTAG & 60 & 30 & AB161667 & $(\mathrm{CT}) 7$ & 225 & Perfect \\
\hline CS2056 & GAGAGACATGGGGGAAGAGG & GGTTCTAACACATGAATGGC & 60 & 30 & AB161668 & $(\mathrm{GA}) 20(\mathrm{GA}) 7$ & 295 & Compound \\
\hline CS2165 & GAGAGAGGTTTGAAGAGAGA & СССТСАТСТТСТАТСААСТС & 60 & 35 & AB161669 & $\begin{array}{c}(\mathrm{AG}) 6(\mathrm{GA}) 30(\mathrm{AG}) \\
40(\mathrm{GA}) 7(\mathrm{GA}) 25\end{array}$ & 395 & Compound \\
\hline CS2169 & GTAGAGGAGGGATATAGAGT & TCCTTGTCCATCTCTCTTTA & 55 & 30 & AB 161670 & $(\mathrm{GA}) 9$ & 141 & Perfect \\
\hline CS2230 & AGACATAAAGAGGGAGGTAGAG & TACTCTTGCTGACTGGTCCG & 60 & 30 & AB161671 & $(\mathrm{GA}) 9$ & 119 & Perfect \\
\hline CS2245 & GAGGCAAAGGTAGAGGTGAA & CCСТCCCAAGTTCTAAGTAA & 60 & 30 & AB161672 & $(\mathrm{GA}) 9$ & 167 & Perfect \\
\hline $\mathrm{CS} 2260$ & GGAGGGTAGATAGAGAAAATAG & ТСТАССТАССТСТСТТСССА & 60 & 30 & AB161673 & (GA)39 & 206 & Perfect \\
\hline CS2294 & ТTТССТСТTCСАТСТСАССС & TCATGCTCCATTACGAATCT & 60 & 30 & AB161674 & (CT)30 & 129 & Perfect \\
\hline CS2484 & TGAGAAAGGGAGAGAGGGAT & СССССТТСТСТТТТТСАСТС & 60 & 30 & $\mathrm{AB} 161675$ & $(\mathrm{GA}) 13$ & 158 & Perfect \\
\hline
\end{tabular}

a Putative PCR fragment sizes were deduced from sequences of genomic clones between forward and reverse primers. 
Table IV. Polymorphic level and deviation from Hardy-Weinberg expectation of microsatellite markers with more than two alleles in 28 screening panel samples.

\begin{tabular}{|c|c|c|c|c|c|c|}
\hline Marker & NA & PIC & Segregation & Expected & $\chi^{2}$ & Probability \\
\hline CJS0002 & 10 & 0.779 & $38: 28: 39: 39$ & $1: 1: 1: 1$ & 2.389 & 0.496 \\
\hline CJS0091 & 9 & 0.807 & $41: 35: 30: 37$ & $1: 1: 1: 1$ & 1.755 & 0.625 \\
\hline CJS0268 & 11 & 0.591 & $74: 74$ & $1: 1$ & 0.000 & 1.000 \\
\hline CJS0331 & 3 & 0.160 & $76: 71$ & $1: 1$ & 0.170 & 0.680 \\
\hline CJS0333 & 10 & 0.850 & $39: 45: 34: 31$ & $1: 1: 1: 1$ & 3.027 & 0.388 \\
\hline CJS0336 & 9 & 0.734 & Invariant & - & - & - \\
\hline CJS0356 & 8 & 0.754 & $41: 39: 39: 27$ & $1: 1: 1: 1$ & 3.370 & 0.338 \\
\hline CJS0401 & 9 & 0.817 & $42: 34: 32: 27$ & $1: 1: 1: 1$ & 3.459 & 0.326 \\
\hline CJS0455 & 6 & 0.540 & $80: 70$ & $1: 1$ & 0.667 & 0.414 \\
\hline CJS0485 & 9 & 0.825 & $31: 86: 31$ & $1: 2: 1$ & 3.892 & 0.143 \\
\hline CJS0520 & 5 & 0.408 & $76: 72$ & $1: 1$ & 0.108 & 0.742 \\
\hline CJS0527 & 3 & 0.526 & Invariant & - & - & - \\
\hline CJS0537 & 10 & 0.837 & Invariant & - & - & - \\
\hline CJS0584 & 9 & 0.794 & $28: 40: 38: 41$ & 1:1:1:1 & 2.905 & 0.407 \\
\hline CJS0665 & 8 & 0.733 & $33: 32: 43: 39$ & $1: 1: 1: 1$ & 2.197 & 0.532 \\
\hline CJS0686 & 6 & 0.729 & $72: 78$ & $1: 1$ & 0.240 & 0.624 \\
\hline CJS0838 & 8 & 0.736 & $73: 73$ & $1: 1$ & 0.000 & 1.000 \\
\hline CJS0955 & 5 & 0.664 & $72: 75$ & $1: 1$ & 0.061 & 0.805 \\
\hline CS1218 & 3 & 0.181 & Invariant & - & - & - \\
\hline CS1219 & 6 & 0.351 & Invariant & - & - & - \\
\hline CS1226 & 6 & 0.731 & $77: 66$ & $1: 1$ & 0.846 & 0.358 \\
\hline CS1281 & 8 & 0.768 & $31: 44: 40: 35$ & $1: 1: 1: 1$ & 2.587 & 0.460 \\
\hline CS1289 & 10 & 0.834 & Invariant & - & - & - \\
\hline CS1364 & 4 & 0.433 & Invariant & - & - & - \\
\hline CS1450 & 3 & 0.234 & Invariant & - & - & - \\
\hline CS1522 & 9 & 0.744 & $63: 87$ & $1: 1$ & 3.840 & 0.050 \\
\hline CS1525 & 8 & 0.461 & $30: 75: 34$ & $1: 2: 1$ & 1.101 & 0.577 \\
\hline CS1579 & 4 & 0.438 & $84: 66$ & $1: 1$ & 2.160 & 0.142 \\
\hline CS1671 & 6 & 0.394 & Invariant & - & - & - \\
\hline CS1737 & 10 & 0.864 & $42: 40: 35: 31$ & $1: 1: 1: 1$ & 2.000 & 0.572 \\
\hline CS1895 & 10 & 0.801 & $41: 39: 29: 36$ & $1: 1: 1: 1$ & 2.283 & 0.516 \\
\hline CS1906 & 3 & 0.156 & Invariant & - & - & - \\
\hline CS2024 & 20 & 0.919 & $38: 33: 37: 39$ & $1: 1: 1: 1$ & 0.565 & 0.904 \\
\hline CS2048 & 4 & 0.246 & Invariant & - & - & - \\
\hline CS2056 & 6 & 0.727 & $83: 66$ & $1: 1$ & 1.940 & 0.164 \\
\hline CS2165 & 15 & 0.908 & Invariant & - & - & - \\
\hline CS2169 & 7 & 0.636 & $65: 85$ & $1: 1$ & 2.667 & 0.102 \\
\hline CS2230 & 3 & 0.334 & Invariant & - & - & - \\
\hline CS2245 & 3 & 0.308 & Invariant & - & - & - \\
\hline CS2260 & 10 & 0.859 & $57: 94$ & $1: 1$ & 9.066 & 0.003 \\
\hline CS2284 & 10 & 0.823 & $78: 70$ & $1: 1$ & 0.432 & 0.511 \\
\hline CS2294 & 4 & 0.601 & 44:99:8 & $1: 2: 1$ & 31.795 & 0.000 \\
\hline
\end{tabular}

Table V. Rank correlation coefficients [Kendall's (Kendall 1970)], between two measures of variation (the number of alleles (NA) and polymorphism information content (PIC)) on one hand, and four measures of length [the number of repeats (NOR), the number of nucleotides per repeat (NNR), total number of nucleotides (TNN) and the number of nucleotides in the microsatellites' flanking regions (NNF)] on the other.

\begin{tabular}{lcccc}
\hline & NOR & NNR & TNN & NNF \\
\hline NA & $0.3973 * * *$ & $0.4987 * * *$ & 0.0570 & -0.0655 \\
PIC & $0.4447 * * *$ & $0.5230 * * *$ & 0.1357 & -0.1468 \\
\hline
\end{tabular}

the priming sequences in C.japonica. Our low rate of null allele detection suggests that the high mutation rate at priming sequences is not pandemic in this species. Null alleles can cause a number of problems, such as underestimations of the number of heterozygotes in population genetic studies of natural populations, overestimates of the inbreeding rate in mating system analysis using open-pollinated seeds, and underestimates of pollen dispersal distance in paternity analyses. Our newly developed microsatellite markers revealed a lower rate of null allele detection than the microsatellite markers previously developed by Moriguchi et al. [20]. Therefore, these markers are likely to be valuable tools, not only for genetic mapping, but also for analyses of population genetics and reproduction ecology in natural populations [7, 13].

Acknowledgements: The authors wish to thank to K. Mikuni, K. Iwata, M. Ishiki and Y. Taguchi for laboratory assistance. We are grateful to S. Ueno, T. Sugaya and Y. Moriguchi for helpful advice about the development of the microsatellite-enriched library. We also thank to D. Pot and S.C. González-Martínez for translation of the summary to French. This study was supported by grants from the Program for Promotion of Basic Research Activities for Innovative Biosciences (PROBRAIN) and the Pioneer Special Study of the Ministry of Agriculture, Forestry and Fisheries in Japan.

\section{REFERENCES}

[1] Amarasinghe V., Carlson J.E., The development of microsatellite DNA markers for genetic analysis in Douglas-fir, Can. J. For. Res. 32 (2002) 1904-1915.

[2] Armour J.A.L., Neumann R., Gobert S., Jeffreys A.J., Isolation of human simple repeat loci by hybridization selection, Hum. Mol. Genet. 3 (1994) 599-605.

[3] Besnard G., Achere V., Rampant P.F., Favre J.M., Jeandroz S., A set of cross-species amplifying microsatellite markers developed from DNA sequence databanks in Picea (Pinaceae), Mol. Ecol. Notes 3 (2003) 380-383.

[4] Bostein D., White R.L., Skolnick M., Davis R.W., Construction of a genetic linkage map in man using restriction fragment length polymorphisms, Am. J. Hum. Genet. 32 (1980) 314-331.

[5] Callen D.F., Thompson A.D., Shen Y., Phillips H.A., Richards R.I., Mulley J.C., Sutherland G.R., Incidence and origin of "null" alleles in the $(\mathrm{AC})_{\mathrm{n}}$ microsatellite markers, Am. J. Hum. Genet. 52 (1993) 922-927. 
[6] Decroocq V., Favé M.G., Hagen L., Bordenave L., Decroocq S., Development and transferability of apricot and grape EST microsatellite markers across taxa, Theor. Appl. Genet. 106 (2003) 912922.

[7] Derory J., Mariette S., Gonzaléz-Martínez S.C., Chagn D., Madura D., Gerbera S., Brach J., Persyn F., Ribeiro M.M., Plomiona C., What can nuclear microsatellites tell us about maritime pine genetic resources conservation and provenance certification strategies? Ann. For. Sci. 59 (2002) 699-708.

[8] Echt C.S., May-Marquardt P., Survey of microsatellite DNA in pine, Genome 40 (1997) 9-17.

[9] Echt C.S., May-Marquardt P., Hseih M., Zahorchak R., Characterization of microsatellite markers in eastern white pine, Genome 39 (1996) 1102-1108.

[10] Elsik C.G., Williams C.G., Low-copy microsatellite recovery from a conifer genome, Theor. Appl. Genet. 103 (2001) 1189-1195.

[11] Fischer D., Bachmann K., Microsatellite enrichment in organisms with large genomes (Allium cepa L.), Biotechniques 24 (1998) 796-802.

[12] Fleischer R.C., Loew S., Construction and screening of microsatellite-enriched genomic libraries, in: Ferraris J., Palumbi S. (Eds.), Molecular zoology: advances, strategies and protocols, Wiley-Liss, New York, 1995, pp. 459-468.

[13] González-Martínez S.C., Gerber S., Cervera M.T., Martínez-Zapater J.M., Alía R., Gil L., Selfing and sibship structure in a two-cohort stand of maritime pine (Pinus pinaster Ait.) using nuclear SSR markers, Ann. For. Sci. 60 (2003) 115-121.

[14] Iwata H., Ujino-Ihara T., Yoshimura K., Nagasaka K., Mukai Y., Tsumura Y., Cleaved amplified polymorphic sequence markers in sugi, Cryptomeria japonica D. Don, and their locations on a linkage map, Theor. Appl. Genet. 103 (2001) 881-895.

[15] Jones A.G., Stockwell C.A., Walker D., Avise J.C., The molecular basis of a microsatellite null allele from the white sands pupfish, J. Hered. 89 (1998) 339-342.

[16] Kendall M.D., Rank Correlation Methods, 3rd ed., Charles Griffin, 1970, London.

[17] Kölliker R., Jones E.S., Drayton M.C., Dupal M.P., Forster J.W., Development and characterisation of simple sequence repeat (SSR) markers for white clover (Trifolium repens L.), Theor. Appl. Genet. 102 (2001) 416-424.

[18] Kostia S., Varvio S.L., Vakkari P., Pulkkinen P., Microsatellite sequences in Pinus sylvestris, Genome 38 (1995) 1244-1248.

[19] Kuramoto N., Kondo T., Fujisawa Y., Nakata R., Hayashi E., Goto Y., Detection of quantitative trait loci for wood strength in Cryptomeria japonica, Can. J. For. Res. 30 (2000) 1525-1533.

[20] Moriguchi Y., Iwata H., Ujino-Ihara T., Yoshimura K., Taira H., Tsumura Y., Development and characterization of microsatellite markers for Cryptomeria japonica D. Don, Theor. Appl. Genet. 106 (2003) 751-758.

[21] Moriguchi Y., Matsumoto A., Saito M., Tsumura Y., Taira H., DNA analysis of clonal structure of an old growth, isolated forest of Cryptomeria japonica in a snowy region, Can. J. For. Res. 31 (2001) 377-383.

[22] Mukai Y., Suyama Y., Tsumura Y., Kawahara T., Yoshimaru H., Kondo T., Tomaru N., Kuramoto N., Murai M., A linkage map for sugi (Cryptomeria japonica) based on RFLP, RAPD, and isozyme loci, Theor. Appl. Genet. 90 (1995) 835-840.

[23] Murray M.G., Thompson W.F., Rapid isolation of high molecular weight plant DNA, Nucleic Acids Res. 8 (1980) 4321-4325.

[24] Nikaido A.M., Ujino T., Iwata H., Yoshimura K., Yoshimaru H., Suyama Y., Murai M., Nagasaka K., Tsumura Y., AFLP and CAPS linkage maps of Cryptomeria japonica, Theor. Appl. Genet. 100 (2000) 825-831.

[25] Panaud O., Chen X.L., McCouch S.R., Frequency of microsatellite sequences in rice (Oryza sativa L.), Genome 38 (1995) 1170-1176.

[26] Sambrook J., Russell D.W., Molecular Cloning: a Laboratory Manual, 3rd ed., Cold Spring Harbor Laboratory Press, New York, 2001.

[27] Taira H., Tsumura Y., Tomaru N., Ohba K., Regeneration system and genetic diversity of Cryptomeria japonica growing at different altitudes, Can. J. For. Res. 27 (1997) 447-452.

[28] Tani N., Takahashi T., Iwata H., Mukai Y., Ujino-Ihara T., Matsumoto A., Yoshimura K., Yoshimaru H., Murai M., Nagasaka K., Tsumura Y., A consensus linkage map for sugi (Cryptomeria japonica) from two pedigrees, based on microsatellites and expressed sequence tags, Genetics 165 (2003) 1551-1568.

[29] Tani N., Tsumura Y., Sato H., Nuclear gene sequences and DNA variation of Cryptomeria japonica samples from the postglacial period, Mol. Ecol. 12 (2003) 859-868.

[30] Tautz D., Hypervariability of simple sequences as a general source for polymorphic DNA markers, Nucleic Acids Res. 17 (1989) 6463-6471.

[31] Tomaru N., Tsumura Y., Ohba K., Genetic variation and population differentiation in natural populations of Cryptomeria japonica, Plant Species Biol. 9 (1994) 191-199.

[32] Tsumura Y., Suyama Y., Yoshimura K., Shirato N., Mukai Y., Sequence-tagged-sites (STSs) of cDNA clones in Cryptomeria japonica and their evaluation as molecular markers in conifers, Theor. Appl. Genet. 94 (1997) 764-772.

[33] Tsumura Y., Tomaru N., Genetic diversity of Cryptomeria japonica using co-dominant DNA markers based on sequenced-tagged sites, Theor. Appl. Genet. 98 (1999) 6396-404.

[34] Vandeven W.T.G., McNicol R.J., Microsatellites as DNA markers in Sitka spruce, Theor. Appl. Genet. 93 (1996) 613-617.

[35] Weber J.L., Informativeness of human $(\mathrm{dC}-\mathrm{dA}) \mathrm{n}(\mathrm{dG}-\mathrm{dT}) \mathrm{n}$ polymorphisms, Genomics 7 (1990) 524-530.

[36] Yazdani R., Scotti I., Jansson G., Plomion C., Mathur G., Inheritance and diversity of simple sequence repeat (SSR) microsatellite markers in various families of Picea abies, Hereditas 138 (2003) 219-227.

[37] Zhou Y., Bui T., Auckland L.D., Williams C.G., Undermethylated DNA as a source of microsatellites from conifer genome, Genome 45 (2002) 91-99. 